\title{
THERMAL EXPERIMENTAL INVESTIGATION OF TRADITIONAL HOUSES IN SOUTH EGYPT, (Toshky Region)
}

\author{
M.M. Abd EI Razek \\ Ass.Prof. Building Research Center, Cairo Egypt B.O.Box 1770
}

\begin{abstract}
This Paper presents a thermal investigation of four traditional houses tested experimentally under the effect of external climatic conditions of hot dry region in Egypt (Toshky region). The external and internal walls of the test house were constructed from local sandstone blocks with $50 \mathrm{~cm}$ thick. The ratio between the external openings and the external walls surfaces areas is less than $10 \%$. The external wall is covered internally with $2-3 \mathrm{~cm}$ cement mortar plasters, while the internal walls covered with $2-3 \mathrm{~cm}$ cement plaster from both sides. Volts and domes covered the roof of the test houses. The external surface of the roof covered with $2-3 \mathrm{~cm}$ white cement mortar plaster.

Results demonstrated that the local building materials (sandstone) suppress the swing of external outdoor air temperature and stabilize the indoor air temperature at average level below the average of outdoor air temperature by about $2-3{ }^{\circ} \mathrm{C}$ during the hottest period. The results also show that it is possible to maintain the indoor air temperature significantly below the average of the outdoor air temperature by about $4-5^{\circ} \mathrm{C}$, when modern insulating materials together with the local building materials are used. Besides, the use of passive cooling systems (evaporative cooling) maintained the indoor climate in the thermal human comfort zone.
\end{abstract}

Manuscript received from Dr . M.M.Abd El Razek

Accepted on : $22 / 9 / 2002$

Engineering Research Journal Vol 25, No 4, 2002 Minufiya University, Faculty Of

Engineering, Shebien El-Kom, Egypt, ISSN 1110-1180 


\section{KEYWORDS:}

Climate, Comfort, Thermal, Traditional Building, Specific heat, Toshky Region, Evaporative Cooling

\section{2- INTRODUCTION}

Hot dry Regions are found in Egypt between $22^{\circ}$ to $30^{\circ}$ north latitude. The following features characterize this region during the summer season; aridity, high summer daytime temperatures, large diurnal temperature variation, low relative humidity, and high solar radiation. Toshky region is a desert region located in the south east of Egyptian western desert at the Tropic Cancer $\left(23.5^{\circ} \mathrm{N}\right)$. A large desert reclamation project is being implemented and provided with Nile water, therefore new cities are being established in this region. In such climate thermal human comfort is crucial to provide the reasonable environment for these new communities, and to save energy. In Egypt different field measurements and theoretical studies were carried out to investigate the thermal performance of the traditional: houses under the effect of local external climatic conditions. The results of these studies showed that, dry and spray water shading roofs devices, double walls, ventilated double walls, insulating roofs, and air gap roofs improve the internal environmental conditions under the external climatic conditions of Cairo $\left(30 \mathrm{~N}^{0}\right)$ Egypt. $^{(1,2,3,4)}$

A passive cooling system was studied by many other authors, the results of these investigations showed that, evaporative cooling, roof ponds, indirect evaporative cooling by wetted walls, plants and earth as a cooling source are an integrated part of the guidelines for building design in hot dry region. ${ }^{(5)}$ Evaporative cooling study was carried out by the author on the prefabricated house located in Toshky region under the external climatic conditions and during the hottest period. Results indicated that an average indoor air temperatures of about $24^{\circ} \mathrm{C}$ was obtained when the average outdoor air temperature reached $38^{\circ} \mathrm{C} .{ }^{(7)}$

\section{1- BACK GROUND OF THE PROBLEM}

\subsubsection{Comfort in Hot-Dry Region}

The thermal comfort of human being is governed by many physiological mechanisms of the body and these vary from person to person. In any particular thermal environment it is difficult to get more than $50 \%$ of the people affected to agree that the conditions are comfortable. Personal (activity, clothing, age and sex) and physical environmental variables (air temperature, mean radiant temperature, relative humidity and wind speed) are the principle factors affecting the human thermal comfort. The design strategies for cooling firstly dependent on the determination of the upper and lower limits of thermal comfort zone. In hot and dry region climate the evaporation of moisture from the skin is considered basic variable affecting rising the upper limit of comfort zone. Humphreys and Nicol (1998) present a formula to determine the "Indoor Comfort" temperature, $\mathrm{T}_{\mathrm{n}}$ relative to an exponentially weighted ruining average outdoor temperature, $\mathrm{T}_{n m o}$ and applicable to free running building (with ought mechanically narrowly controlled indoor temperature $\left(T_{n}\right.$ $=0.534 \mathrm{~T}_{\mathrm{rmo}}+12.9$ ). Table (1) shows The upper limit temperature of the comfort zone during the summer time in Toshky region.

\section{2-2 Design Strategies for Building in Toshky Region}

From the climatic applicability aspect, the ability to keep the indoor condition within the comfort level without mechanical cooling, by designing light-colored, high mass, well 
Table (1): The Upper limit temperature of comfort zone during summer time in Toshky region.

\begin{tabular}{|c|c|c|c|c|c|c|}
\hline Months & May & June & July & August & September & October \\
\hline Max. Temperature, $\left({ }^{\circ} \mathrm{C}\right)$ & 40.8 & 40.6 & 43.5 & 46.5 & 43.5 & 40 \\
\hline Min. Temperature, $\left({ }^{\circ} \mathrm{C}\right)$ & 25 & 26 & 27 & 28 & 26 & 25 \\
\hline Ave. Temperature, $\left({ }^{\circ} \mathrm{C}\right)$ & 32.8 & 32.8 & 35.3 & 37.3 & 34.8 & 32.5 \\
\hline $\begin{array}{c}\text { Upper limit of comfort } \\
\text { zone }\left({ }^{\circ} \mathrm{C}\right)\end{array}$ & 30.4 & 30.4 & 31.8 & 32.8 & 31.5 & 30.3 \\
\hline
\end{tabular}

insulation traditional buildings, depends mainly on the outdoor average temperatures, so one can surmised the following assumptions:.

- In summer months where the average outdoor temperature is about 20-25 oC, indoor conditions can be maintained at comfort level through the day without intensive night ventilation i.e traditional buildings are not sensitive to external climatic conditions.

- In summer months where the average outdoor air temperature is up to about $25-29{ }^{\circ} \mathrm{C}$. Intensive night ventilation reduced the indoor maximum temperature to a level close to the average temperature, i.e traditional building is more sensitive to the external climatic conditions.

- In summer months where the average of the temperature is up to $30^{\circ} \mathrm{C}$, the traditional building is high sensitive to external climatic conditions. In this case some additional passive or low- energy cooling system, such as evaporative cooling, is needed to ensure indoor comfort.

The chart of design strategies for cooling building on hot dry region is based on the bioclimatic chart developed by Milne and Givoni ${ }^{(6)}$. The hottest months in Toshky region are July, August and September ${ }^{(7,8)}$. The results show that, many passive cooling strategies are needed to achieve the indoor climate of buildings near or in the human comfort zone under the effect of external climatic conditions 2 evaporation cooling is considered adequate passive cooling.

\subsubsection{High-mass cooling with night ventilation.}

This strategy may be applied in buildings under the external climatic conditions during May, June and September. During these period the envelope massive surfaces must provided to store the day's heat. Also, because there are more hours of daylight and few of night, the ventilation must occur more quickly and thoroughly, probably using fans. Also the building switches from a thermally closed conditions by day to an open conditions at night.

\subsubsection{Evaporative cooling.}

This design strategy is adequate during months of July, August and September(hottest and dry period). This design strategy relies on the principle that when moisture is added to air, the air increases in relative humidity while decreasing in dry bulb temperature. However, large quantities of both water and outdoor air are needed.

\section{3- EXPERIMENTAL MODEL}

\subsection{Experimental Test Houses}

Three old traditional houses were studied experimentally to investigate the thermal performance of buildings. The first building is "El Awamat house", and it has external

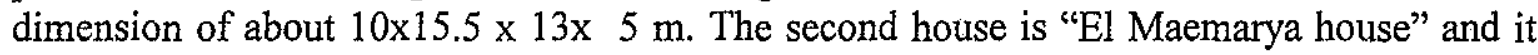
has external dimensions of about $35 \times 13 \times 4.5 \mathrm{~m}$. The third house is "El Garad house" and it has external dimensions of about $31 \times 16.5 \times 5 \mathrm{~m}$. (see Fig. $(1,2)$ ). 
All these houses have burning walls, constructed from heavy local sandstone with $50: \mathrm{cm}$ thick and have internal cement plaster of about $2.5-3 \mathrm{~cm}$. The roofs are covered by domes and vaults which are constructed from cement bricks of about $15 \mathrm{~cm}$ thick. Domes and vaults are covered externally and internally by $2.5 \mathrm{~cm}$ cement plaster.

\subsection{Evaporative cooling:}

Light weight prefabricated building in El Behera Comp. Camp and it is investigated experimentally to study the effect of evaporative cooling on the indoor climatic conditions in Toshky region during the hottest period. The testing prefabricated building has external dimensions of about $10 \times 10 \times 3.5 \mathrm{~m}$. The characteristic features of the evaporative cooler used in this building are shown in table (2).

Table: (2) Specification of evaporative cooler used in prefabricate house Toshky

\begin{tabular}{|c|c|c|c|}
\hline \multirow[t]{3}{*}{ FAN } & Dia $x$ Width & $\mathrm{mm}$ & $460 \times 380$ \\
\hline & Shaft \& Bearings & $\mathrm{mm}$ & $22 \mathrm{sg} / 6006-2 \mathrm{RS}$ \\
\hline & Pulley PCD & $\mathrm{mm}$ & $205 \times \mathrm{A}$ \\
\hline \multirow{3}{*}{ a } & 2 Speed (High/Low) & $\mathrm{pm}$ & $420 / 280$ \\
\hline & Variable Speed range & $\mathrm{pm}$ & 420 to 175 \\
\hline & V Belt & & A 54 \\
\hline \multirow[t]{8}{*}{ MOTOR } & Output (High/Low) & Watts & $750 / 225$ \\
\hline & Type & & PSC \\
\hline & 2 Speed (High/Low) & $\mathrm{pm}$ & $1400 / 960$ \\
\hline & Variable Speed Range & $\mathrm{pm}$ & 1400 to 600 \\
\hline & Voltage/phases/Hz & & $240 / 1 / 50$ \\
\hline & Current & $\mathrm{pm}$ & 4.8 \\
\hline & Pulley Type & & Variable / pitch \\
\hline & Púlley PCD & $\mathrm{mm}$ & $85-60 \times a$ \\
\hline \multirow[t]{4}{*}{ PUMP } & Type & & Centrifugal \\
\hline & Rating (Input) & Watts & 40 \\
\hline & Flow Rate & $\mathrm{I} / \mathrm{min}$ & 19.5 \\
\hline & Voltages/phases $/ \mathrm{Hz}$ & & $240 / 1-50$ \\
\hline \multirow[t]{4}{*}{ FIL TER PAD } & Number of Pads & & 4 \\
\hline & Pad Area & $\mathrm{M}^{2}$ & 2.8 \\
\hline & Max Velocity & $\mathrm{M} / \mathrm{sec}$ & 0.80 (@80 pa) \\
\hline & Saturation Efficiency & $\%$ & $85.5 \cdot \cdots 4$ \\
\hline \multirow[t]{2}{*}{ WATER } & Tank Capacity & litres & 25 \\
\hline & Drain & $\mathrm{mm}$ & $40 \mathrm{BSP}$ \\
\hline \multirow[t]{6}{*}{ SHIPPING } & Dimensions & $\mathrm{mm}$ & $945 \times 1005 \times 1185(\mathrm{H})$ \\
\hline & (Inc. Pallet) & & \\
\hline & Voilume & $\mathrm{M}^{2}$ & 1.13 \\
\hline & Mass-Shipping & $\mathrm{Kg}$ & 83 \\
\hline & Mass-Nett Unit & $\mathrm{Kg}$ & 68 \\
\hline & Mass-Operating & $\mathrm{Kg}$ & 95 \\
\hline
\end{tabular}

* The table contain is Breez. Compu. Cool Istrala.

\subsection{Experimental devices:}

The external climate conditions were measured using Casella automatic weather station. Solar energy was measured using SS-100 sensor. The temperatures were measured using thermocouples type $\mathrm{T}$ attached to scanning thermometer. The predicted mean votes (PMV) and predicted percentage of dissatisfied (PPD) were obtained using internal weather station (IC-500) according to Winles application software HB 3264-03. The results of predicted mean voets is demonstrated in table (3). 
Table (3): The Predicted mean votes according to Funger equation predicted by (IC-500)

\begin{tabular}{|c|c|c|c|c|c|c|}
\hline Very Hot & Hot & $\begin{array}{c}\text { Slightly } \\
\text { Hot }\end{array}$ & Comfort & $\begin{array}{c}\text { Slightly } \\
\text { Cool }\end{array}$ & Cool & Very Cool \\
\hline+3 & +2 & +1 & 0 & -1 & -2 & -3 \\
\hline
\end{tabular}

\section{RESULTS AND DISCUSSION}

\section{1- Climate of Toshky Region}

The climate of Toshky region is considered as a very hot dry climate, it can be divided into three distinguishable periods; warm climate during the period from November to February, hot and dry during March to June and October, and very hot-dry period during July to September. This classification was based on environmental measurements carried out by Egyptian Building Research Center for a period of two year table (4). The very hot-dry period is the most critical period for the house design. During this period the study and observation of the author proved the unfeasibility of achieving indoors thermal comfort by using traditional buildings. Complementary effects between various aspects of housing design in hot arid zone and passive cooling systems are essential. ${ }^{(6,7)}$

Table: (4): Maximum and minimum climatic external conditions in Toshky region ${ }^{*}$

\begin{tabular}{|c|c|c|c|c|c|c|c|c|c|}
\hline \multirow[t]{2}{*}{ Months } & \multicolumn{3}{|c|}{$\begin{array}{c}\text { OUTDOOR } \\
\text { TEMPERATURE } \\
\left({ }^{\circ} \mathrm{C}\right)\end{array}$} & \multicolumn{3}{|c|}{$\begin{array}{l}\text { Relative Humidity } \\
\text { (Avarage) } \\
\text { (\%) }\end{array}$} & \multicolumn{2}{|c|}{$\begin{array}{l}\text { Wind Spced } \\
\text { averagc } \\
(\mathrm{m} / \mathrm{s})\end{array}$} & \multirow[t]{2}{*}{$\begin{array}{l}S . R . \\
(\mathrm{Max}) \\
\left(\mathrm{W} / \mathrm{m}^{2}\right)\end{array}$} \\
\hline & Max. & MIN & Mean & Max & Min & Mean & SPeed & Direction & \\
\hline January & 25 & 8 & 16.5 & 48 & 21 & 34.5 & 1.5 & $\overline{\mathrm{EN}}$ & 800 \\
\hline February & 22.7 & 11.4 & 17.0 & 37.9 & 10.8 & 24.3 & 3.4 & $\mathrm{EN}$ & 725 \\
\hline March & 30.1 & 11.5 & 20.8 & 43.2 & 12.0 & 27.5 & 5.1 & N-NW & 1000 \\
\hline April & 39.0 & 21.0 & 30.0 & 31.4 & 12.6 & 22.0 & 3.4 & $\mathrm{NW}-\mathrm{N}$ & 1025 \\
\hline May & 40.8 & 25.0 & 32.8 & 33.1 & 13.1 & 23.1 & 3.1 & $N$ & 1160 \\
\hline June & 40.6 & 26.0 & 32.8 & 28.0 & 12.0 & 20.0 & 2.5 & $\mathrm{NW}$ & 1055 \\
\hline July & 43.5 & 27.0 & 35.3 & 30 & 16.5 & 23.5 & 7.4 & N-NE-NW & 1125 \\
\hline August & 46.5 & 28.0 & 37.3 & 37.0 & 17 & 27.0 & 7.5 & $\mathrm{~N}$ & 1150 \\
\hline September & 43.5 & 26.0 & 34.8 & 39.0 & 15.2 & 27.0 & 7.1 & $\mathrm{~N}-\mathrm{NE}$ & 900 \\
\hline October & 38.0 & 22.0 & 30.0 & 35 & 16 & 25.5 & 6.5 & $\mathrm{NNE}$ & 850 \\
\hline November & 33 & 18.7 & 25.8 & 45.0 & 16.0 & 30.5 & 5 & $\mathrm{~N}-\mathrm{NE}$ & 800 \\
\hline December & 28.0 & 14.0 & 21.0 & 55.0 & 23.0 & 39.0 & 3.5 & NE-N & 780 \\
\hline
\end{tabular}

\subsection{Building Materials:}

Table (5) shows the thermal properties of local building materials in Toshky region. It is obvious that all the local building materials have a very low thermal resistance and high diurnal heat capacity, when compared with values recommended by Givioni for typical desert with a diurnal range of $15^{\circ} \mathrm{C}$ and maximum solar intensity of $1100 \mathrm{~W} / \mathrm{m}^{2(1)}$. So, it may be concluded that modern thermal insulation materials, together with the local materials are needed in this region.

Table (5): Thermal Properties of local building materials in Toshky region. 


\begin{tabular}{|l|c|c|c|}
\hline \multicolumn{1}{|c|}{ Thermal properties } & Sandstone & limestone & Clay brick \\
\hline Density, $\left(\mathrm{Kg} / \mathrm{m}^{2}\right)$ & $2200-2300$ & $1650-1800$ & 175 \\
\hline Thermal Conductivity, $\left(\mathrm{W} / \mathrm{m}^{\circ} \mathrm{C}\right)$ & $1.5-1.8$ & $0.93-1.4$ & 0.5 \\
\hline Thermal resistance, $(50 \mathrm{~cm}$ thick $),\left(\mathrm{m}^{20} \mathrm{C} / \mathrm{W}\right)$ & $0.5-0.58$ & $0.728-0.8$ & 1.381 \\
\hline
\end{tabular}

\subsection{Thermal Performance of Traditional Building.}

Figure (3) diurnal variation of outdoor, indoor air temperatures and indoor predicted mean votes (PMV) measured in "El Awamat house " under the external climatic conditions of Toshky region during two successive days 26, 27 September 1999. The outdoor air reaches to its maximum temperature of about 43 and 43.5 respectively for the two successive daýs (26 and 27 September),1999. The Maximum and minimum outdoor air temperature occur at 6 a.m and 14 p.m respectively during the first day, while the maximum of the outdoor air temperature of the second day occurs later than the maximum of outdoor of the first day by about two hours. Also from the observations and measuring data carried out by the author for four years on the region, one can see that the occurrence of the maximum outdoor air temperature is dependent on the air speed and direction on the region. Also it can be seen that the average value of the outdoor temperature is 35.5 . The indoor air reached to its maximum temperature of about $36{ }^{\circ} \mathrm{C}$ during the two days at the evening (20.p.m hour). While it is reached to minimum temperature of about $30^{\circ} \mathrm{C}$ at $10 \mathrm{a} . \mathrm{m}$ hour. The results show that the average indoor air temperature is lower than the average outdoor temperature by about $2.5^{\circ} \mathrm{C}$ only. This is due to the high mass of building materials used in external envelope of the test house. The figure illustrated the predicted mean vote which it is reached to about +1.8 . This number indicate hot indoor environment during the day and night time is very hot. Also the results demonstrated that about $65 \%$ of the people live in this house is felt discomfort during this period of the year.

Fig.(4) shows the diurnal outdoor and indoor air temperatures measured in El-Mamarya house in two successive days during May 1999. The results demonstrated that the average of indoor air temperature of unventilated (closed) room is increased by about $2.5^{\circ} \mathrm{C}$ rather tan the average air temperature of ventilating. Also it can be seen that the temperature of unventilated roof have the same performance of the outdoor temperature. This performance show the, night ventilation is of primary importance for cooling of the building's structural mass on the indoor temperature during the summer seasons.

Fig.(5) shows the diurnal outdoor, indoor air temperature and solar radiation incident on horizontal surfaces for El- Garad houses. Figure (5.a) illustrates the diurnal climatic factors i.e solar radiation and outdoor air temperature for the days of 14-19 May 1999. The maximum outdoor air temperatures reaches to $35{ }^{\circ} \mathrm{C}$ occurs at about 15 a.m hours. The outdoor air temperature has a mean value of about $27.5^{\circ} \mathrm{C}$ for sex days. The peaks of the solar intensity occurs at 13 p.m (local time of Egypt). Figure (5.b to d) show the diurnal indoor air temperature of three rooms in Garad house for sex successive days during (14-19) May 1999. The temperature performance of the three rooms have the same performance during the day and night hours. This is due to the high mass of building materials used in external envelop. The indoor air temperatures of the three rooms reached to $35^{\circ} \mathrm{C}$ as maximum value, and to $25^{\circ} \mathrm{C}$ as minimum values. The indoor air temperature has a mean value of about $27.5^{\circ} \mathrm{C}$ for sex days, and this value is coincide with the mean value of the outdoor. 


\subsection{Evaporative Cooling.}

Fig.(6.a\&b) illustrated the diurnal outdoor, indoor, global temperature and predictedicmean vote of test prefabricated house during 12- July 1999. The evaporative cooler is op oferated during 24 hours. The indoor air reaches to its maximum temperatures of about $26^{\circ} \mathrm{C}$ at $18 \mathrm{p} . \mathrm{m}$ hour. Also the figure show that the PMV reached to about +1 Indicate Suitable thermal Iuman senisation indoor climate. The predicted percent dissatisfied (PPD) is reached to about $30 \%$ It is clear from the figure that the evaporative cooling is a good passive system used during the hottest period in Toshky region.

\section{CONCLOSIONS}

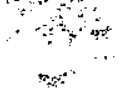

The results of this investigation concluded that :

1-Insulating materials must be added to the local building materials to improve the theral characteristics of local building materials.

2-The indoors climatic conditions in traditional houses in hot period in Toshky region have very uncomfortable interiors during the summer night hours, forcing the inhabitants to sleep on the roof or in open area and may be considered as a high thermal stress.

3- According to the relative humidity of the region, evaporative cooling is considered a good passive system to improve the indoor air climate.

4-Although people living in hot regions are acclimatization to the prevailing thermal environment would prefer higher temperatures and would suffer less in hot environment. The results of IC-500 system indicated that PMV and PPD scales demonstrated that, people in traditional houses in Toshky region would suffer discomfort sensation.

\section{8-REFERENCES}

1. B. Givoni, "Climate Consideration in Building and Urban design"; Van Nostrand Reionold,(1998).

2. J. S. Hsieh Solar Energy Engineering Prentice-Hall, Englewood Cliffs; New Jersey, (1986).

3. M.M Razek, G. B. Hanna, E.M. El Salam and N. Farag "Computer Simulation and Thermal Measurements of Passive Heated and Ventilated Buildings", $3^{\text {rd }}$ International PLEA Conference, Mexico City, Mexico 6-11 August PP..952-959 (1984).

4. M.M Razek, G. B. Hanna, E.M. El Salam and N. Farag "computer Simulation and Thermal Measurements of Passive Heated and Ventilated Buildings", $3^{\text {rd }}$ Internationge: PLEA Conference, Maxico City, Mexico 6-11 August PP..952-959 (1984).

5. M.M Razek, G. B. Hanna, E.M. El Salam and N. Farag "computer simulation and Thermal

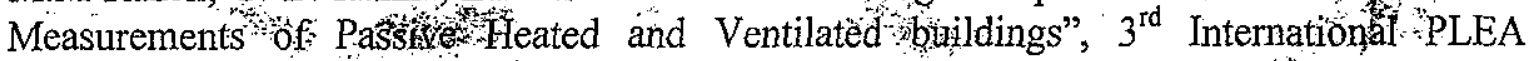
Conference, Mexico City, Mexico 6-11 August PP..952-959 (1984).

6. G.B. Hanna and M.H. Khalil, "Thermal Investigation of Shaded and Insulation Roof in Hot Arid Climate", Passive and Low Energy Architecture conference.(1984).

7. B.Givioni "Man Climate and Architecture", 2" edition, London, Applied" science Publishers. (1976)

8. Bioclimatic Studies of Toshky Region and thermal performance of local building", $1^{\text {st }}$ Report Egyptian building Research Center, Cairo Egypt, Jun, (1999).

9. Bioclimatic Studies of Toshky Region and Thermal Performance of Local Building", $2^{\text {nd }}$ Report Egyptian Building Research Center, Cairo Egypt, Jun, (1999). 

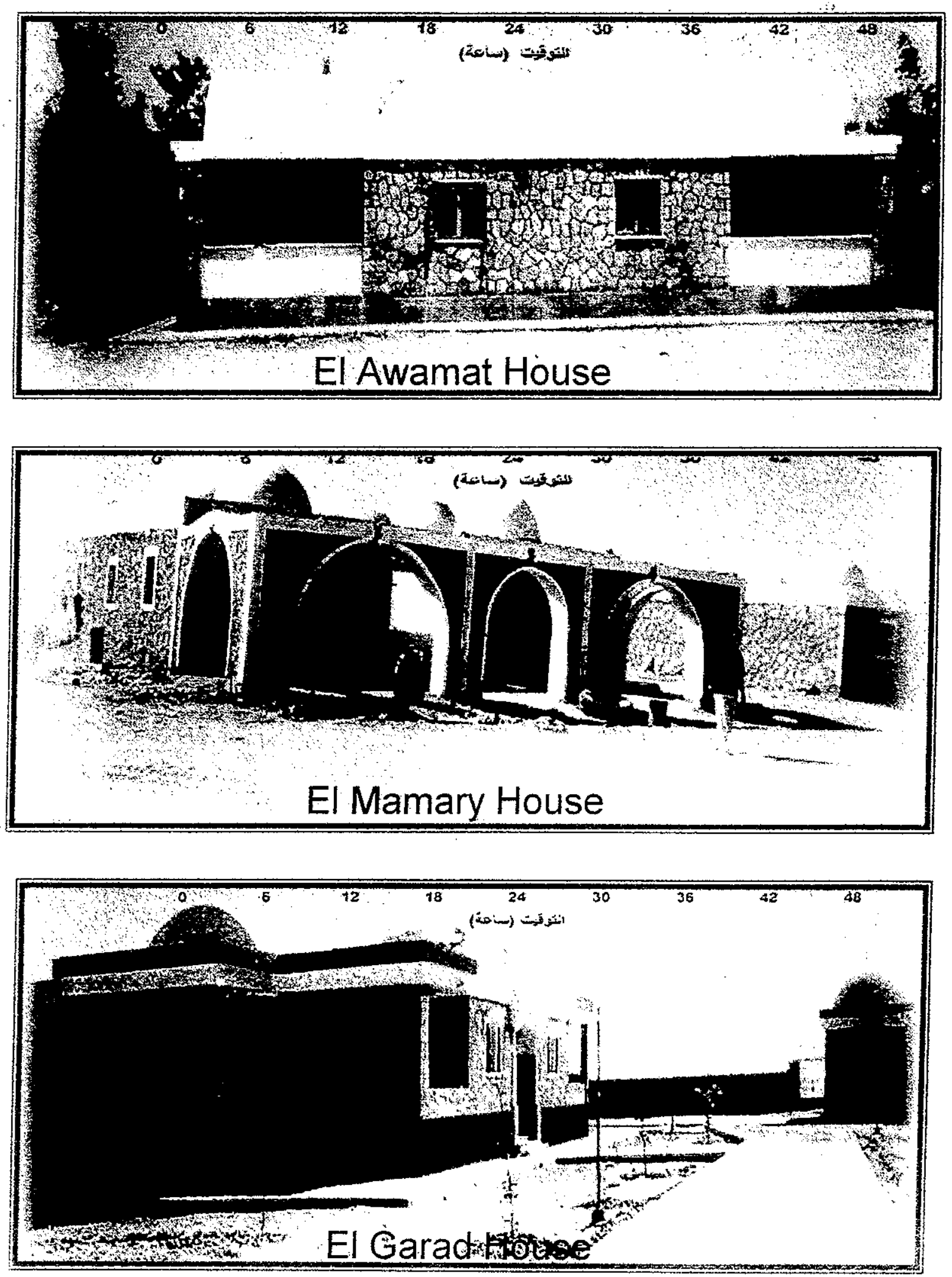

Fig (1): Three Traditional Houses investigated Thermally in Toshky Region 


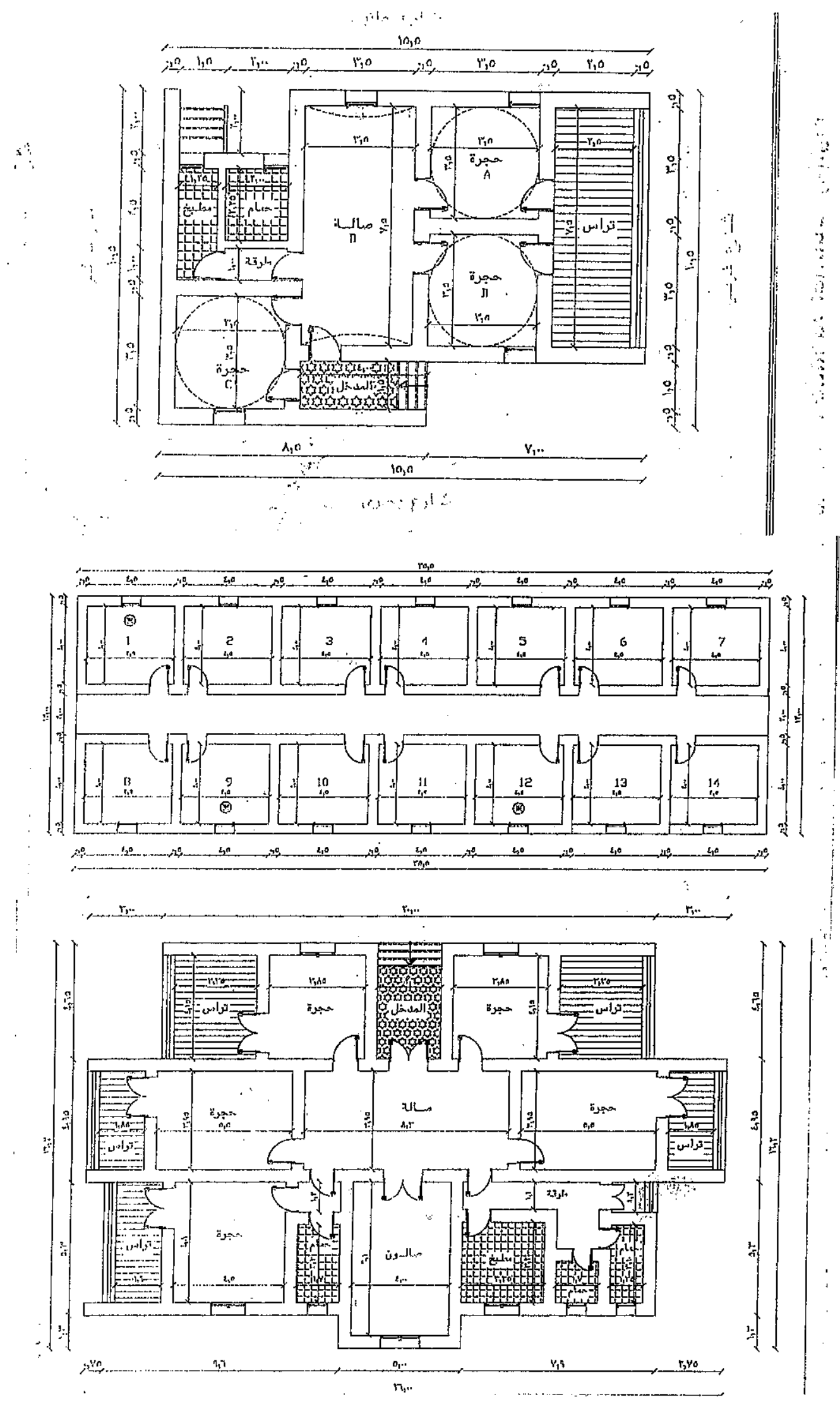

Fig(2) : Horizontal Plane of Thee Houses On Toshka Region 


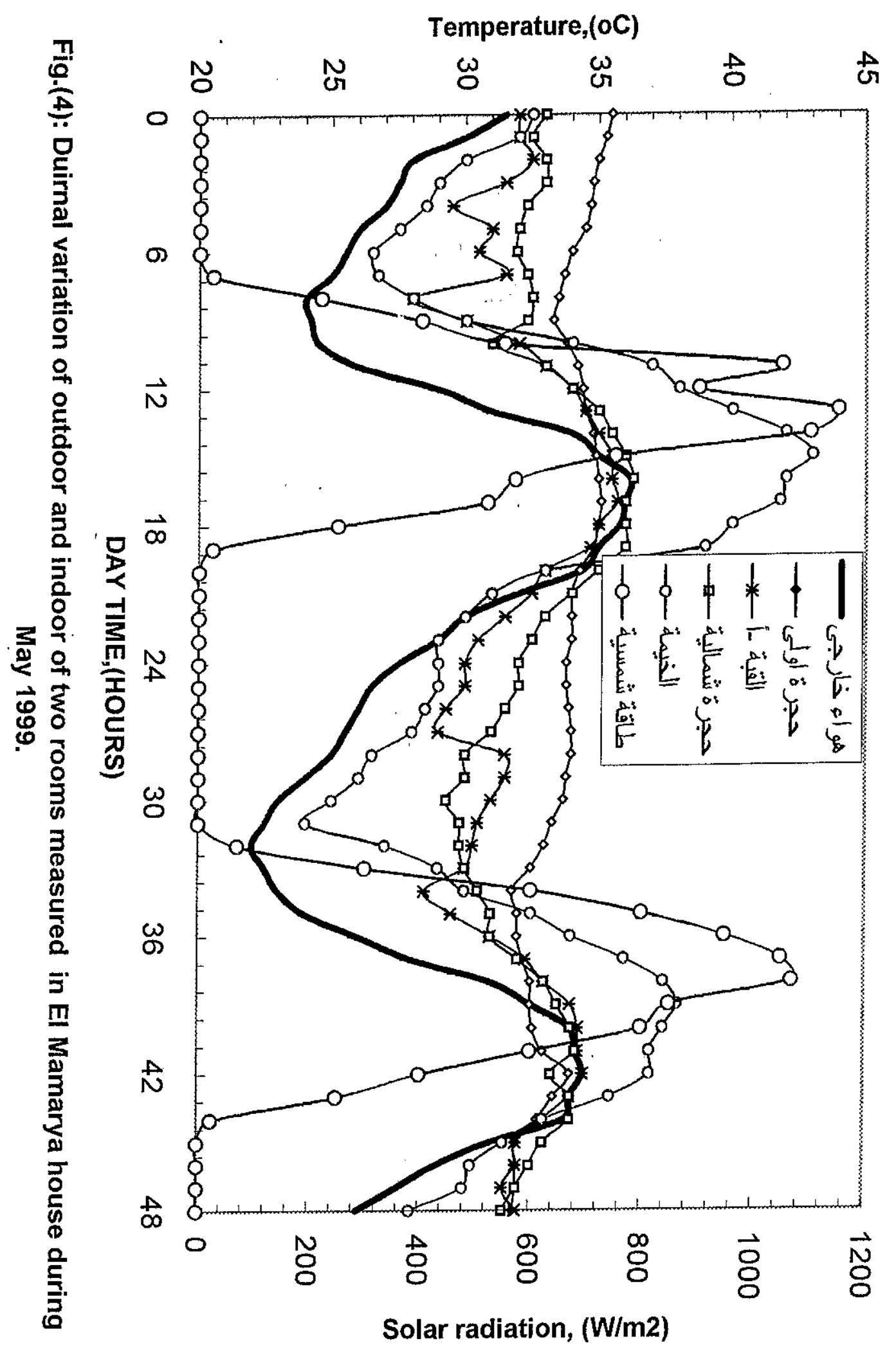



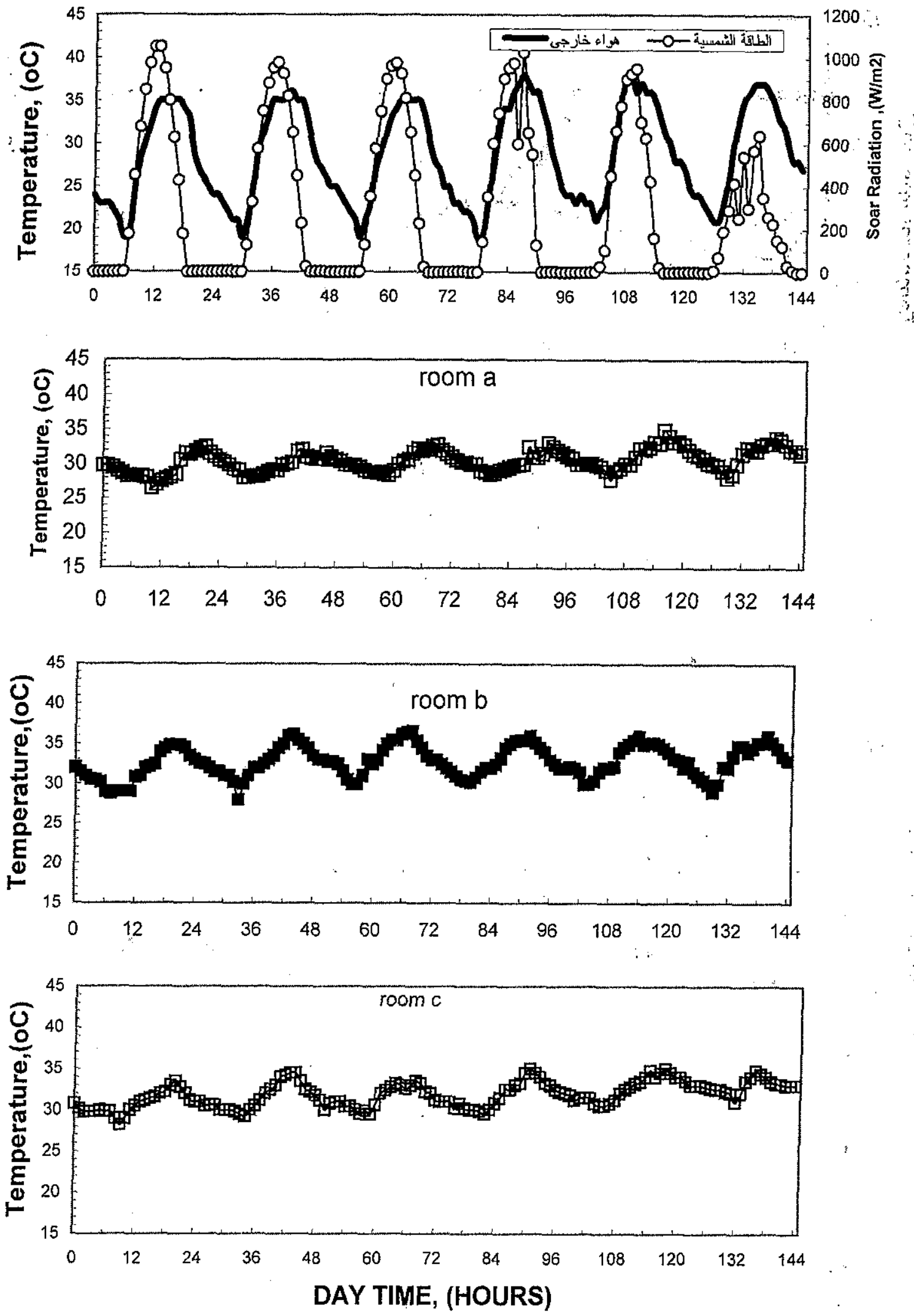

Fig.(5)Diurnal variation of outdoor and indoor air temperatures of three rooms in El Garade house during 14-19 May, 


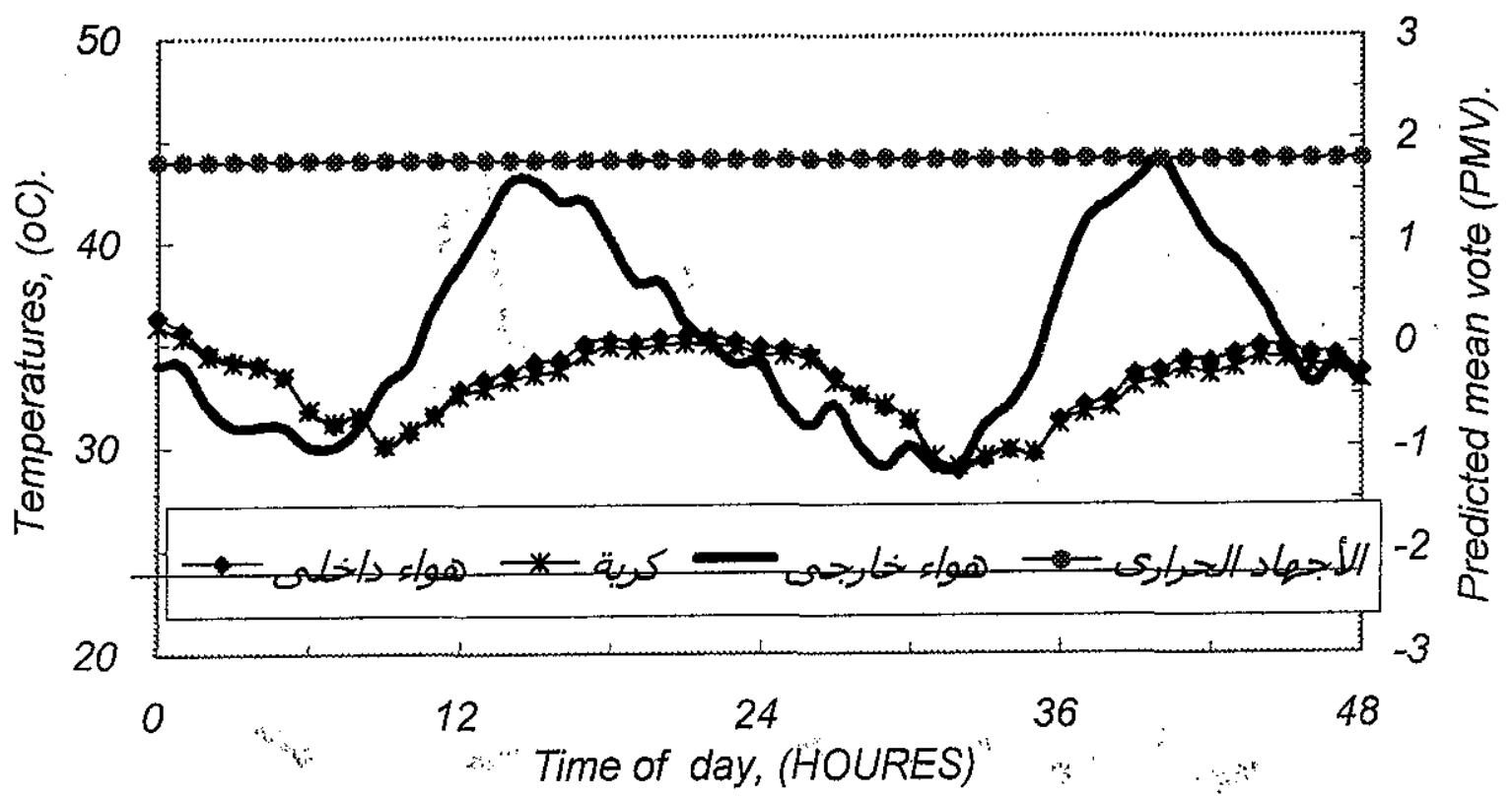

Fig.(3.a): Diurnal variation of outdoor, indoor air temperatures and indoor Predicted mean voit (PMV) measured in El Awamat house during 26, 27 Septemper 1999.

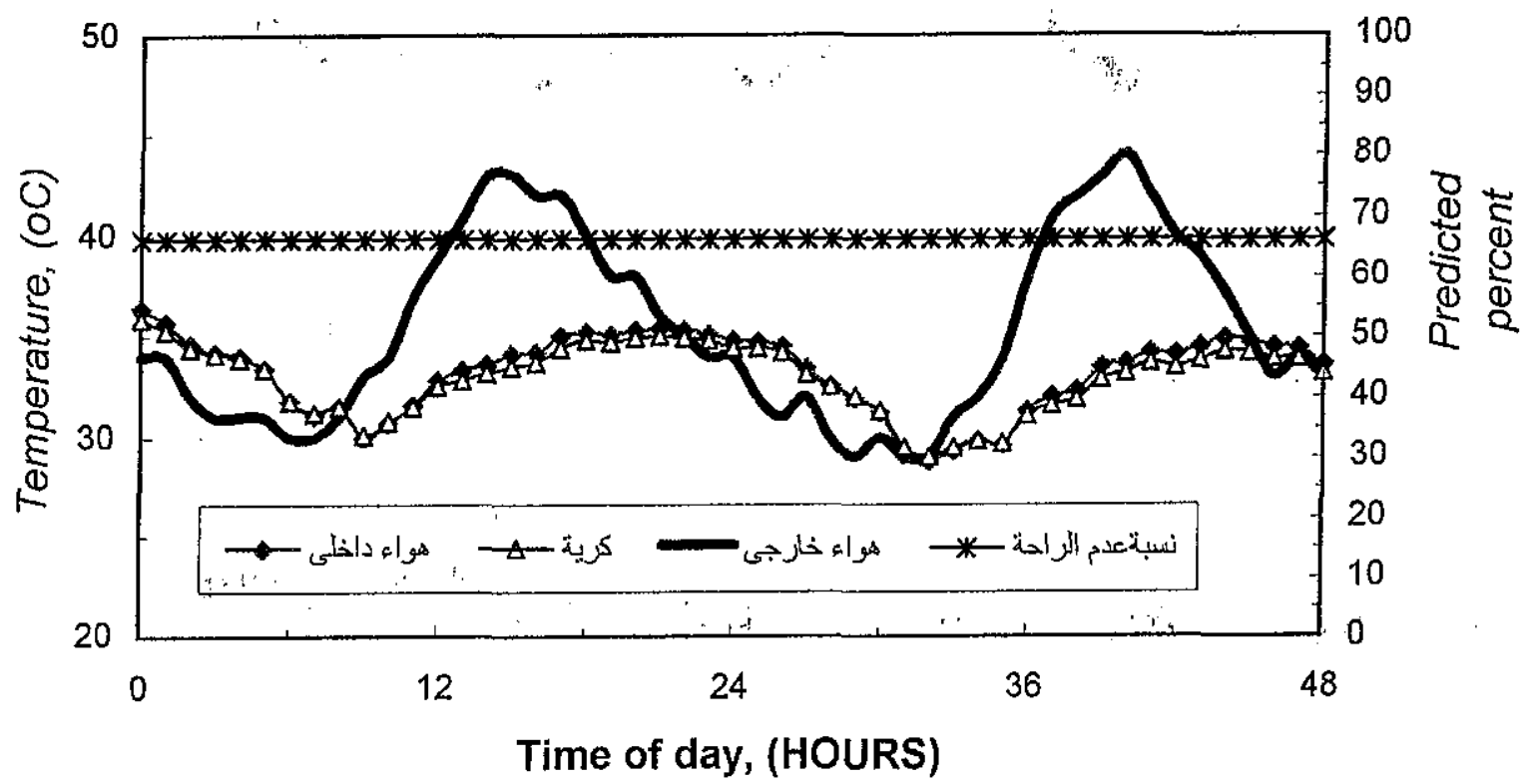

Fig.(3.b): Diurnal vairation of outdoor, indoor air temperatures and predicted dissatisfied (PPD) measured in Awamat house during 26,27 Septemper, 1999. 


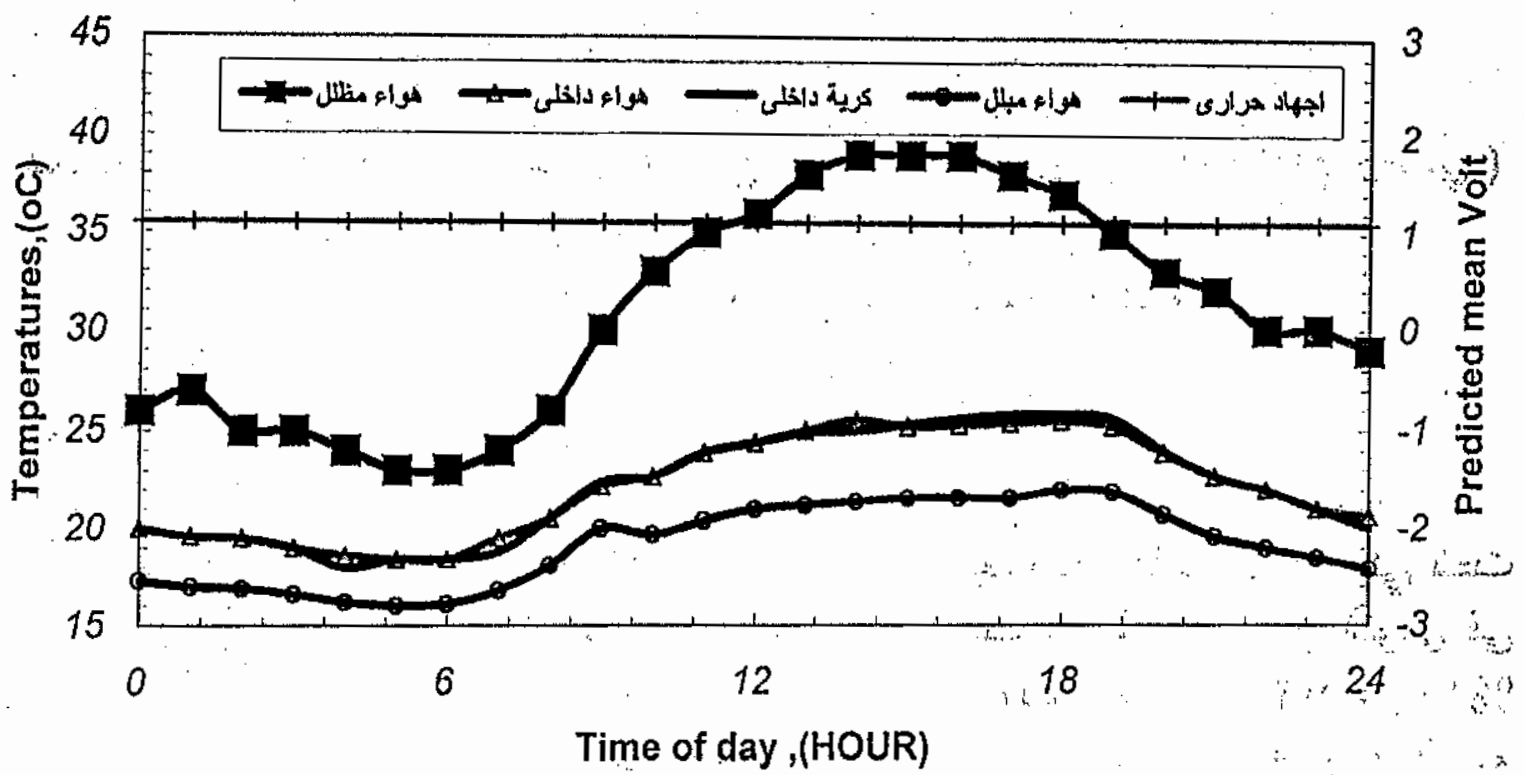

Fig.(6.a):Diurnal Variation Of The outdoo, indoor temperature and predict mean voit (PMV) during 12 July 1999.

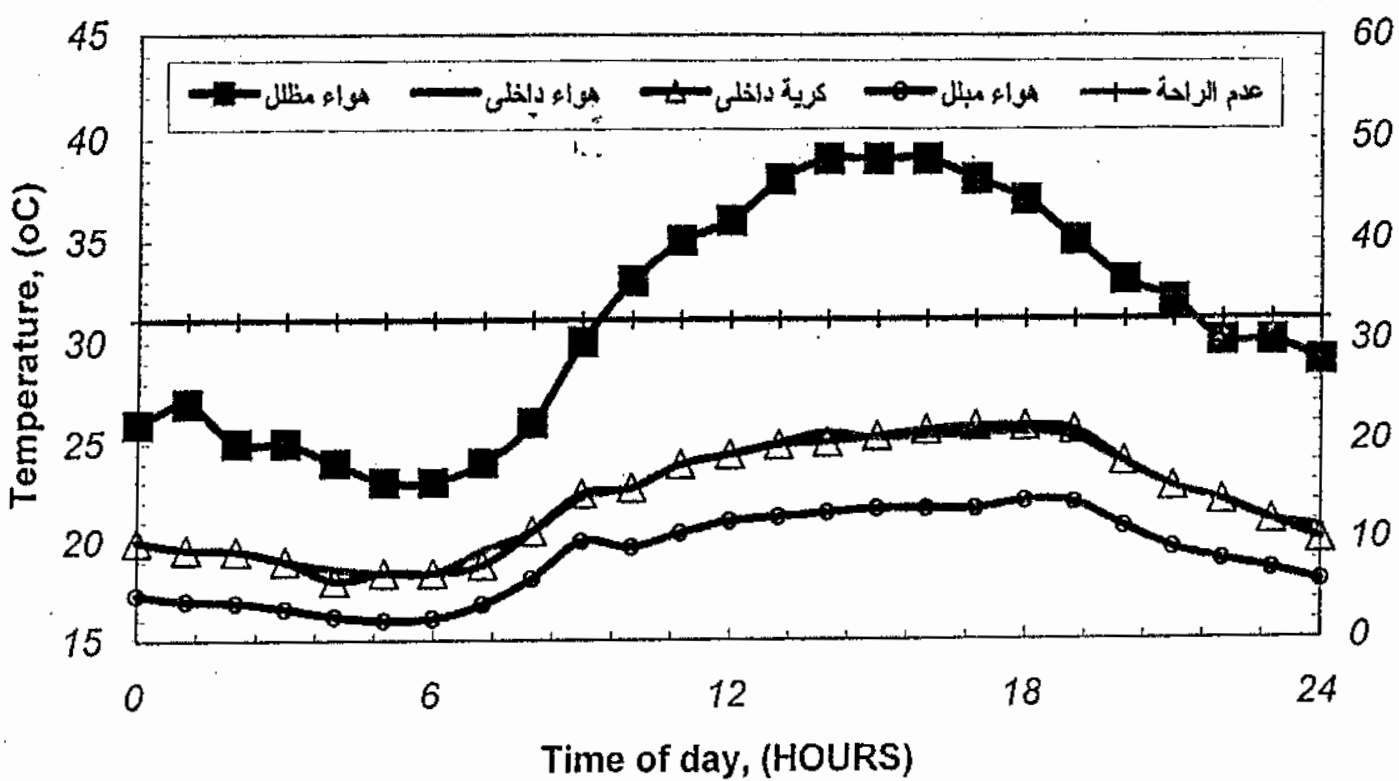

Fig.(6.b): Diurnal variation of outdoor,indoor, globle temperature and Predicted percent dissatisfied(PPD) measured During 12, July,1999 in lightweight icon structure. 


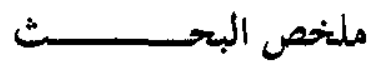

تقييم معدلات الأداء الصراري لبعض النماذج السكنية في جنوب الوادي ( إقليم توشكي ) د. / محمد محمود عبد الرازق مركز بحوث الإسكان والبناء"

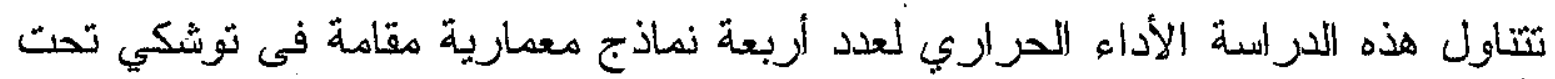

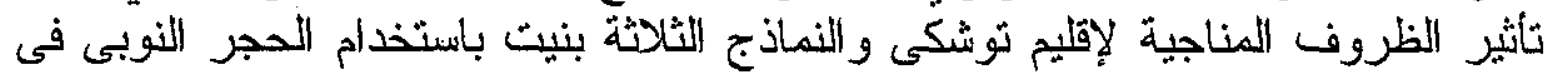

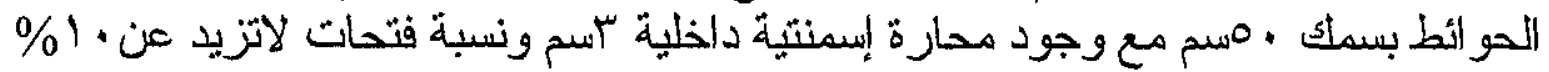

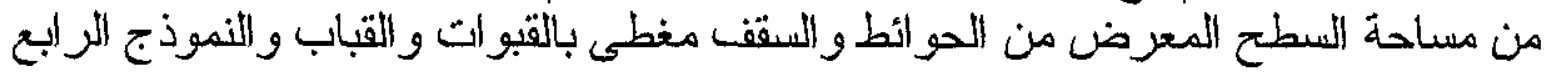

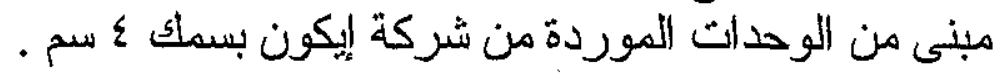

وأوضدث نتائج الدراسة الحاجة الماسة إلى إعادة النظر فى الستخدام مواد البناء التقليدية

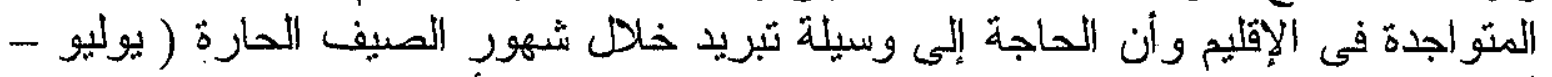

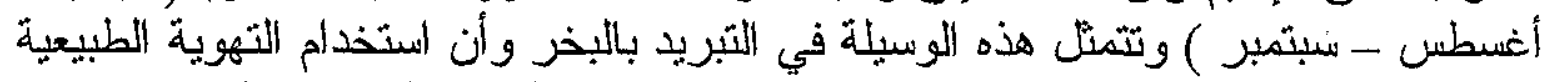
ليلا يؤدى بالاقتز اب بالقر اغات المعمارية الأخلية إلى منطقة الر احة الحر ارية للئل الإنسان 